\title{
The Implementation of Affective Assessment For Islamic Education In High School 1 Pariangan
}

\author{
Muhammad Kristiawan, Adri Jumeldi, Syarwani Ahmad, Nova Asvio \\ ${ }^{1}$ Management of Education, Graduate Program, PGRI University of Palembang, South Sumatera, Indonesia. \\ ${ }^{2}$ State High School 2 Lintau Buo, Tanah Datar, West Sumatera, Indonesia. \\ ${ }^{3}$ Management of Education, Graduate Program, PGRI University of Palembang, South Sumatera, Indonesia. \\ ${ }^{4}$ Management of Education, Graduate Program, PGRI University of Palembang, South Sumatera, Indonesia.
}

\section{Address For Correspondence:}

Muhammad Kristiawan, Management of Education, Graduate Program, PGRI University of Palembang, South Sumatera, Indonesia E-mail: muhammad.kristiawan@yahoo.co.id

Received 1 May 2016; accepted 6 July 2016; published 13 July 2016

\section{A B S T R A C T}

In this qualitative research, the researchers analyzed the implementation of affective assessment for Islamic education in High School 1 Pariangan. The interview, observation and documentation were used in collecting data. The result obtained indicate that the implementation of affective assessment for Islamic education was run well. It was marked by making lesson plan and making instrument of affective assessment and also giving appropriate score of students' affective in instructional process. Teacher of Islamic education in High School 1 Pariangan has begun affective assessment by making the grating assessment. Teacher used observation sheet to measure spiritual and social behavior of students. Affective assessment through observation was done by the teacher when the students did group discussion in instructional process.

Key words: Affective Assessment, Islamic Education, High School, Pariangan

\section{INTRODUCTION}

This research starts from interview with Imal Darlianto, December 22 ${ }^{\text {nd }}, 2015$ that High School 1 Pariangan has various achievements and often follow a religious education and religious competition both in the district level and regency level. The following table was some achievements of High School 1 Pariangan last two years:

Table 1: School's Achievement
\begin{tabular}{|l|l|l|l|l|}
\hline No & Achievment & Year & Level & Statement \\
\hline 1 & Adiwiyata & 2013 & National & First rank \\
\hline 2 & Basket Ball & 2015 & Regency & First rank \\
\hline 3 & Foot Ball (LPI) & 2014 & Regency & First rank \\
\hline 4 & Uda Uni & 2013 & Regency & First rank \\
\hline 5 & Futsal & 2014 & Regency & First rank \\
\hline 6 & Foot Ball & 2013 & Regency & The third rank \\
\hline 7 & Futsal & 2013 & Regency & The third rank \\
\hline 8 & Nasyid & 2014 & Regency & The third rank \\
\hline 9 & MSQ & 2014 & Regency & The fourt rank \\
\hline
\end{tabular}

Published BY AENSI Publication

(C) 2016 AENSI Publisher All rights reserved

This work is licensed under the Creative Commons Attribution International License (CC BY).

http://creativecommons.org/licenses/by/4.0/

\section{(C) (†) Open Access}

To Cite This Article: Muhammad Kristiawan, Adri Jumeldi, Syarwani Ahmad, Nova Asvio., The Implementation Of Affective Assessment For Islamic Education In High School 1 Pariangan. Research Journal of Social Sciences, 9(4): $1-8,2016$ 
Based on the table above the researchers were interested in conducting the research in this school, because the more achievements that the school get, there the better construction pattern of the students. This is also related to the Islamic education subjects.

Three are teaching domains as intellectual goals [5]. Those domains are the cognitive, psychomotor, and affective. From those domains, some teachers often only implement the cognitive. It could be happened because the target from cognitive domain is student's intellectual progress [2]. Cognitive knowledge include factual knowledge, conceptual knowledge, procedural knowledge, and metacognition of knowledge. Cognitive process include remembering, understanding, applying, analyzing, evaluating, and making or inventing. The purpose of achieving cognitive domain was supported by using a model of learning which has the simplicity of operational level such as the expository method. For the psychomotor domain is used to know the learners' performance results, it can be done if the teachers use instructional practices performed in the laboratory. It is rarely done by the teachers for various reasons such as the lack of preparation and take quite a long time. Both domains are still found on some teachers who have a high creativity in teaching. For the target of the affective includes correctness, and the ability to solve problems logically and systematically, this domain is a domain that is shown by behavior relate to emotional such as feelings, values, interests, awareness, motivation, and attitude.

There are five levels for taxonomy of affective domain arranged in hierarchy as according to complexity [5]. The fifth level of the taxonomy of the affective domains are follows 1) taxonomy affective called "accept", at this level, the participants receive new information and have ability to respond of stimulus selectively, the example is the presence of students in class and focused to the teacher or a friend that discuss about lesson materials; 2) "respon" range from compliance with a voluntary response to have a teste of our statisfaction in doing what is needed, for example, students involvement in classroom activities; 3) "cherish", at this level, students manifest consistent behavior with certain truth, for example, when a student demonstrates gestures about agreement toward someone, he/she can explain it well; 4) "organization" or "conceptualization", students set of values into a value system that is used to respond the various situations. The increasing complexity of the forms of learning in the observation that "as a result of affective from simple to complex, the are increasingly becoming internalized and integrated with the behavior of complex system values and beavior paterns [15]. An example of value is conceptualization can combining more than one opinion and compare more than the better opinion; and 5) "characterization", this characterization occurs when students' behavior are consistent and predictable as a lifestyle and characteristic of a person [25].

The goal of affective in learning as a means of cognitive goals is to developing interest and motivation [5]. Motivation is very important to learn and thus is one of the main ways in which the affective domain is used as a means of cognition. To increase the interest and motivation of the learnes is very important to giving attention for the situation of place to learn. Therefore, it can be concluded that the goal of achievement is the affective means to facilitate cognitive learning. Automatically domain appears in every learning, but is rarely found in this research of a teacher. A comprehensive assesment is an essential aspect of any meaningfull education programs. It is aimed to get an intellectual students in the clasification of cognitive knowledge and cognitive process, have good performance and can work diligently, thoroughly, and be able to solve problem systematically.

Assesment as part of the process of education and learning should be done according to the teacher plan. According to [26] explained that the assessment of learning by educators is a process of collection of information to the learners in a spiritual attitude and social attitudes, knowledge, skill and competence which is done in a planned and sistematic way during and after the learning process. Next also emphasized that authentic assessment is a from of that requires students showing attitude, using the knowledge and skills gained from learning in doing tasks in a real situation [26]. It can concluded that a learning process will not be success without any evaluation or assement.either the cognitive or psychomotor, affective. Today teachers often focus on cognitive and psychomotor. According to [22] right now, teachers focus only to paper and pen test so that learning process only focus on cognitive aspect. As a result, the learning targets only limited capabilities in the realm of cognitive and affective domain, putting aside.

Islamic education (PAI) as a main subject in High School along with the purpose of national education [14] that is aimed at the development of potential learners in order to become a man of faith and piety to God almighty, precious, healthy, have learned, acomplished, creative, independent, and become a democratic citizens and responsible. Based on the reality above is considered a very essential research to see how far application of affective assessment in High School 1 Pariangan. It is also in line with the various studies that have been conducted in several countries such as [9] with the title of research the Atitude toward communication skills among students "Teachers" in Jordanian Public Universities said that the developement of affective communication skills is an important part of the teachers'advancement potential. Techers must possess highly developed of the levels communication skill to become a professional succesfull. [21] are researching how the attitude of the students learn in the classroom and in the library with the title Assesing Affective Learning Using a student response system explained that there was a significant improvement in convidence levels for students 
on receiving library instruction, suggesting that library instruction can have a positive influence on affective learning.

\section{Evaluation Terminology:}

"Evaluation" is derived from word evaluation, these words were absorbed into the term Indonesia. Etymologically, the term is derived from the evaluation of the United Kingdom "evaluation" which means the Act or process to determine the value of something or can be defined as Act or process to determine the value of something related to education [3]. In Arabic, evaluation known as imtihan it means tests, or completing as away of judging the end result of the process of eduaction [13]. According to [16] evaluation is "to find out, decide the amount or value" it means an attempt to determne the value or amout. From that sentence indicates that the activities of the evaluation should be done carefully, responsibly, using strategy, and can be accounted for.

According to great dictionary of Indonesia, evaluation is an assessment where the assessment is aimed to excellent people to average people on job or skills. Evaluation is a positive research process and negative or a combination of both [27]. The evaluation is "an independent, systematic investigation into how, why, and to what extents objectives or goals are achieved. It can help the foundation answer key guestions about grants, clusters of grants, components, initiatives, or strategy" [30]. According to [31] evaluation is "getting evidence about changes in behaviors the students, any valid evidence about behaviors that are desired of the educational objecties provides an appropriate method of evaluation". Evaluation according to [30] should using the best methods of its application in learning in order to the facts or valid data was obtained with the aim that would be achieved. According to Worthen and Sanders, the evaluation is looking for something valuable (worth) where it can be the form of information about a program, as well as certain procedures alternative production [19]. [33] defines evaluation is "...a purposeful, systematic, and careful collection and analysis of information used for the purpose of docuenting the affectiveness and impac of programs, establishing accountability and identifying areas needing change and improvement".

In terminology [20] explained that evaluation according to Edwind Wandt contain the meaning act or process of determining the value of something; according to $\mathrm{M}$. Chabib Thoha is an activity that is planned to find out the situation of the object by using instruments and the result is compared with a form of conclusions. The term of evaluation in Islamic discourse cannot be found equivalent exactly, but there are certain long term that leads to the meaning of evaluation. The terms are as follows a) al-hisab, has the meaning estimating, interpreting, calculating, and considering (qur'an al-Baqarah: 284); b) al-Bala', has the meaning trial, test (qur'an al-Mulk: 2); c) al-Hukm, has the meaning veridicting or sentencing (qur'an an-Naml: 78); d) al-Qada, has the meaning verdict (qur'an Thaha: 72); e) al-Nazr, has a meaning look (qur'an an-Naml: 27); f) al-imtihan, has meaning test.

From the opinions above, avaluation can be defined as an activity that is planned to find out the condition of an object by using instruments and the results was compared with a from to obtain a conclusion. In [14] on the national education system chapter I article 1 paragraph 21 explained that the evaluation of education is an activity control, guarantee, and the determination of the quality of education on various educational components on each line, level, and type of education as a form of responsibility for the organization of education.

There are three different terms, they are evaluation, measurement, and assesment. [30] reveals the evaluation is "an independent systematic investigation into how, why, and to what extents objectives or goals area chieved. It can help the fondation answer key question about files of grants, grants, component, intiatives, or strategy". In [14] it was clear that evaluation of the education is an activity control, guarantee the quality of education and determination againts the various components of education at every level and type of education as a form of responsibility from educational organization.

The term measurument is a process of giving score or figures against of a condition or symptoms based on certain rules. In the last measurument is only a part, although a very subtantial part of evaluation. It provides information upon which and evaluation can be used. Education measurement is a process that is the quantified attemps to obtain a representation of the degree to which a trait is possed by a pupil. While the assessment is over the language of the term assessment is an activity to provide a variety of information on an angoing basis and thoroughly about the process and the results that have been achieved in students" [20]. [29] explained that the assessment is an attempt to get a variety of regular information, consistency, and thoroughly about the process and the result of growth and development that has been achieved by students. Meanwhile, [10] defines assessment as a process in collecting various data or information can give an idea about the development of studens learning. From the explanation above, thus it can be stated that assessment is the process of collecting and processing various data or information at regular intervals, consistency, and comprehensive about the process and the results the development of students learnig.

\section{Affective Learning:}


Affective learning or attitude is "concerned with how learners feel while they are learning, as well as with how learning experiences are internlized so they can guide the learner's attitudes, opinion, and behavior in the future' [5]. Affective learning taxonomic or the attitude according to the [5]; 1) receiving; 2) responding; 3) valuating; 4) organization; 5) characterization by a value or set of value. Refer to the taxonomy of learning attitude, [26] about assessment of the results of Learning by Educators in primary and secondary school authentic assessment stated by educators in realm of the spritual and social attitude 1) receive value; 2) responding value; 3 ) esteeming the value; 4) embody values; and 5) practised.

\section{Islamic Education Learning:}

[8] stated that learning is "change in organism due to experience which can affect the organism's behavior. So according to [8] by these new experiences can be learned when affect organisms.

Islamic education and manners are conducted to prepare atudents to convince, understand, and paractice the Islam religion. The education through tutoring, instruction, or training that has been determined to achieve the goals that have been set. Implementation of Islamic education and Manners in the world of education has a very strong base [1] basic juridical, formal juridical base consists of a) the ideal basis, is the state philosophy of Pancasila, the basic precepts of the first deity is ketuhanan yang maha Esa; b) basic constitutional or structural, is the constitution in chapter XI of article 29 paragraph 1 and 2. Religious basis, religious basis is the foundation of which is sourced from the teachings of Islam. According to Islamic teachings, religious education is the order of God and is the embodiment of worship to him. There are many verses in Qur'an that show the order, such as a) the qur'an an-Nahl 125; b) qur'an Ali-Imran 104; and c) qur'an al-Mujadallah 11.

The basis of psychology, is the basis related to psychiatric aspect of the life in society. It is based on human life, individually or as members of the community that exposed to things that made his heart is not tranquil and unconvertible because of frustration (pressure feeling), conflict (innerconflict), and anxiety so that it requires the existence of a handle living (religion). Needs a religion is closely related to the human effort to create a happy life. Therefore, the human condition in fact have claimed that all the needs can be fulfilled in order to realize a harmonious and happy life as well as someone spiritual needs of religion.

Furthermore how is the role of Islamic education and Manners in the framework of the construction of the religiosity learners. Religious attitudes can be understood as an action based on a basic confidence in the values that he believes. Religious attitude in human can be reflected from the way of thinking and acting. Religious attitude is an importaant apart of one's personality that can serve as the moralorientation of the values of the faith, as well as the work ethic in improving social skills.

[1] revealed that the role of Islamic education and manners are as follows 1) religious attitude as to orientation, the internal moral control of religious-oriented moral will be more dominant to do a moral action than external control. This is what distinguishes a moral religious orientation with the moral orientation that is marely based on the outcome of human thought; 2) religious attitude as internalization of religious values, internalization of religious values occurs through understanding the teachings of the religion as a whole and the awarness of the importance of religious teachings, and found possibility for realization in daily life; 3 ) religious attitude as social skill and work ethic, the ability of a person showing the values of religion in his life as a social skill are very strong or weak depending on the religious attitudes that exist in the soul. The religious attitude appears in the form of actions and behaviours towards the environment in harmony with what was ordered by religious teachings.

\section{Research Methods:}

This research includes the types of qualitative research. According to [6] qualitative research tend to collect data in the field at the site where participants experience the issues or problem under study. Qualitative research was research that generates descriptive data on the nature and use a variety of methods. The place of this research was in High School 1 Pariangan Tanah Datar Regency. The object of this research was the assessment of implementation of affective Islamic religious education.

Techniques of data collection used were interviews, observation and study of the document. Definition of interview according to Steward \& Cash as quoted by [7] is "interactional because there is an exchanging, or sharing of role, responsibilities, fellings beliefs, motives, and information. If one person does all of the talking and the other all of the listening, a speech to audience of one, not an interview, is talking place. According to [24] as a scientific method, observation is usually defined as the systematically observations and recording on the researched phenomena. This method was used to see directly how affective assessment implementation in High School 1 Pariangan Tanah datar Regency. According to [3] documentation method is a method by searching data on matters in the form of a note, transkip, books, newspapers, magazines, inscription, the notice of a meeting, legger, agenda. This documentation methods was used to collect data relaed to the topic of the study of the teacher's assessment of the documents come from the subjects of Islamic education in High School 1 Pariangan. 
Research instruments were interview guidelines, observation sheet and cheklist document. The interview conducted in this research was the interview unstructured. Interview unstructured was used to find problems, so that the parties invited to reveal opinions and ideas. Guidelines for interview in this study was about the explanation of the research that was stated in the form of a list of questions. The observation conducted in the research was affective assessment observation by the teacher. Data of the research that has been collected in the form of assessment plan were analyzed in descriptive way. The documents referred to the lesson plan and guidelines or assessment instruments owned by Islamic education teacher in High School 1 pariangan

The data analysis according to [23] constant comparison analysis, and the four analyses comprising ethnographic analysis, domain analysis, taxonomic analysis, componential analysis, and theme analysis. Domain analysis is the analysis which aims to gain public and thorough description of the object of research or social situations. Taxonomic analysis is analysis that explain in more detail the selected domain to be more detailed in order to know its internal structure. The analysis of specific characteristics of komponensial aimed at looking at each internal structure by contrasting between elements. Whereas an analysis of the theme of the culture trying to find connections between domains, and how the relationship with the overall, and further expressed into the theme/title research. [12] suggested that In this view, qualitative data analysis is a continuous, interactive entreprise. In the analysis of qualitative data was done interactively and continuously until it has been completed, so that the data were saturated. Activity in the analysis include the data reduction, the data display, as well as withdrawal and verification of conclusions. In this study the author used data analysis of Miles and Hubberman [12].

\section{RESULTS AND DISCUSSION}

From the observation it can be concluded that assessment of the implementation for Islamic education in High School 1 Pariangan was run well, it can be observed through study document research the learning instruments assessment and devices made by teacher of Islamic education subject in semester 1 year lessons 2015/2016. Affective assessment planning was directly stated in the lesson.

Table 1: Assessment Instruments and techniques

a. Spiritual Attitude (observation, self assessment, assessment betwen friends and journals)

1) Please checklist $(\vee)$ that suitable statements based on your behavior!

\begin{tabular}{|c|c|c|c|c|c|}
\hline \multirow{3}{*}{ No } & \multirow{3}{*}{ Statements } & \multicolumn{4}{|l|}{ Habbits } \\
\hline & & Always & Often & Seldom & Never \\
\hline & & Score 4 & Score 3 & Score 2 & Score 1 \\
\hline 1 & Say greetings before entering class & & & & \\
\hline 2 & Pray before starting work & & & & \\
\hline 3 & Recite Qur'an seriously & & & & \\
\hline 4 & $\begin{array}{l}\text { Convince that the qur'an and the Hadith are the sources } \\
\text { of Islamic law }\end{array}$ & & & & \\
\hline
\end{tabular}

$4=$ always, if always do appropriate statements

$3=$ often, if often perform appropriate representations and sometimes not doing

$2=$ occasionally, if sometimes do and often does not do

$1=$ never, never do

The final value $=$ total score obtained learners X 100

highest score (4)

b. Social Attitudes (Observatons, Self-asssessment, Assessment between friends and journal)

Please checklist $(\vee)$ that suitable statements based on your behavior!

Name :.......

Class :

\begin{tabular}{|c|c|c|c|c|c|}
\hline \multirow{3}{*}{ No } & \multirow{3}{*}{ Statement } & \multicolumn{4}{|l|}{ Habbits } \\
\hline & & Always & Often & seldom & Never \\
\hline & & Score 4 & Score 3 & Score 2 & Score 1 \\
\hline 1 & Respectful in discussion & & & & \\
\hline 2 & Assisting each other in goodness & & & & \\
\hline 3 & Play an active role in the Group & & & & \\
\hline
\end{tabular}

$4=$ always, if always do appropriate statements

$3=$ often, if often perform appropriate representations and sometimes not doing

2 = occasionally, if sometimes do and often does not do

$1=$ never, never do Result

The final value $=$ total score obtained learners X 100

highest score (4) 
The results of the data assessment and implementation of affective planning has done by Islamic education teacher can be seen in the following table.

Table 2: Planning and Implementation of Affective Assessment

\begin{tabular}{|l|l|l|}
\hline Planning of assessment & Result of the Research & Implementations \\
\hline Conformity assessment in the lesson plan with syllabus & $\begin{array}{l}\text { There is conformity assessment on lesson plan } \\
\text { with assessment on the syllabus }\end{array}$ & Yes \\
\hline Make outlines affective Assessment & Teachers had made outlines & Yes \\
\hline $\begin{array}{l}\text { The assessment made at the time of learning (early- } \\
\text { late core PBM) }\end{array}$ & $\begin{array}{l}\text { Teachers conduct the assessment at the time of } \\
\text { learning }\end{array}$ & Yes \\
\hline Assessment coverage to affective aspect that has planned & Assessment is done on aspects of the planned & yes \\
\hline $\begin{array}{l}\text { Conformity assessment techniques related to the aspects } \\
\text { that are assessed }\end{array}$ & $\begin{array}{l}\text { In the assessment of the attitudes the teachers used } \\
\text { observation assessment that has designed }\end{array}$ & Yes \\
\hline $\begin{array}{l}\text { The accuracy of the assessment instrument with the } \\
\text { chosen valuation technique }\end{array}$ & $\begin{array}{l}\text { There is conformity assessment with } \\
\text { assessment instrument }\end{array}$ & Yes \\
\hline Determine the score & Teachers do the scoring & Yes \\
\hline The appropriateness of granting score and assessment & $\begin{array}{l}\text { The teacher gives the score and the value of the } \\
\text { corresponding actual }\end{array}$ & Yes \\
\hline
\end{tabular}

In detail the results of the affective assessment planning can be described as follows. Assessment that created by Islamic Educational teacher in lesson plan has been in accordance with the assessment on the syllabus. The teacher of Islamic education in High School 1 Pariangan has initiated an assessment of attitude by making the lattice of assessment. Assessment technique was suitable with most instruments of assessment that was made by the Islamic education teachers. Teacher used observation sheets to measure spiritual and social behavior of students. Assessment planning that was made by the teachers in the lesson plan have mentioned guidance of assessment score. Affective assessment through observation was done by the teacher when the students did group discussion in instructional process.

From the results of interview conducted with the teachers, it indicate that today most teachers just focused on cognitive assessment, but in High School 1 Pariangan the Islamic Education teachers have implemented the affective assessment. This can be seen from the affective assessment instruments have been designed by the teacher. This is appropriate with [17] that the curriculum reform in terms of teacher autonomy, a key-concept for the comprehension and improvement of the teachers role in education. The change in the curriculum has brought significant innovation regarding the teacher autonomy.

From the research above, the researchers found that affective assessment planning was directly stated in lesson plan. Affective assessment planning on Islamic Education in High School 1 Pariangan was residing in good category. It was indicate that teachers have carried out affective assessment in did learning process that stated in lesson plan. The results of effective assessment data started from the learning process to the evaluation of the leraning outcomes to be implemented properly. The implementation of affective assessment is supported by a variety of other research such as [11] concluded that integrated education character assessment system in recent aplied subject at school has indicated the optimum results.

This research was also supported by similar reseach conducted by [18] which reveal that authentic assessment is an assessment that was conducted through a presentation or performance by students in the form of task or specific activities that directly had the education basic. [34] concluded " authentic assessment is not only difficult notion to define but it is also problematic to collate features within an assessment task that define us it authentic assessment". [4] found that "considerable improvement in highhorder skills of the students. They were actively engaged in planning, collecting information and dissiminating it to the community. Use of rubric for assessment was found to be very effective in determining a path way for both the teacher and students to look for and get to the desirable result"

According to [32] implementation of authentic assessment also is far from perpect because some teacher had not conducted assessment technique completelly. Some teachers had not conducted way of implementing the assessment suitable with curriculum demand. In fact the assessment that was conducted had not implemented all demand assessment technique. Perhaps it was affective by understanding or difficulty in clasroom practicing. Transition can cause the students or the teachersneed a process to conducted the assessment techniques in the clasroom. In addition the problem in assessment was limitation of time.

\section{Conclusion:}

Based on the explanation above the researchers cocluded that the implementation of affective assessment for Islamic education in High School 1 Pariangan was run well. It can be seen from the lesson plan of the teacher which already includes the assessment techniques and it is accompanied by the teachers' proficiency in the affective assessment format of Islamic education and used it in teaching and learning process and the teacher made affective assessments as part of the affective evaluation system.

\section{REFERENCES}


1. Alim, Muhammad, 2011. Islamic Education: The Effort on the Moslems' Character Building. Bandung: PT Remaja Rosdakarya.

2. Anderson, Lorin. W., 1981. Assessing Affective Characteristic in the Schools. Boston: Allyn and Bacon.

3. Arikunto, Suharsimi, 2012. The Basic of Educational Assessment. Jakarta: Bumi Aksara

4. Azim, Sher and Khan, Mohamad, 2012. "Authentic Assessment: An Instruction Tool to Enchance Student Learning”. Academic Research International, 3: 1.

5. Bloom, B.S., D.R. Krathwohl and B.B. Masia, 1964. Taxonomy of Educational Objectives: The Classification of Educational Goal. Handbook II, Affective domain. New York: David McKay Co, Inc.

6. Creswell W. Jhon, 2009. Research Design; Qualitative, Quantitative and Mixed Method Approaches. USA: SAGE Publications.

7. Hardiansyah, Haris, 2011. Qualitative Research Methodology of Social Science. Jakarta: Salemba Humanika.

8. Hintzman, Dauglas L., 1978. The psychology of Learning and Memory. San Francisco: W. H. Freeman \& Company.

9. Ihmeideh, Fathi M., 2010. Attitudes toward Communication Skills among Students' Teachers' in Jordanian Public Universities. Australian Journal of Teacher Education, 35(4), http://files.eric.ed.gov/fulltext/EJ910389.pdf

10. Kunandar, 2014. Authentic Assessment on Curriculum 2013). Jakarta: Raja Grafindo Persada.

11. Lusiana, Diyah and Lestari, 2013. "Affective Assessment Instruments for Civic Education". Journal of Educational Research and Evaluation, 2(1) Graduate Program. State University of Semarang.

12. Miles, Mattew B and Huberman, A Michael, 1994. Qualitative Data Analysis. California: SAGE Publications, Inc

13. Nata, Abuddin, 2005. The Philosophy of Islamic Education. Jakarta: Gaya Media Pratama.

14. National Law of Republic Indonesia No. 20 of 2003.

15. Olatunji, M.O., 2013. "Teaching and Assessing of Affective Characteristics: A Critical Missing Link In Online". International Journal On New Trends In Educational And Their Implications, 4(1): Ijonte.org//?pnum=30\&pt=2013/file/09.on-line.

16. Oxford Learners Pocket Dictionary (new edition). 1995. Oxford University Press.

17. Ozturk, Ibrahim Hakk, 2011. "Curriculum Reform and Teacher Autonomy In Turkey: the Case of the History Teaching”. International Journal of Instruction, 4. www.e-iji.net

18. Pantiwati, Yuni, 2014. "Hakikat Asesmen Autentik Dan Penerapannya Dalam Pembelajaran Biologi". Jurnal Edukasi Matematika dan Sains, 1: 1, Universitas Muhammadiyah Malang

19. Putri, Ratu II., 2010. Assessment Mathematics Education. Palembang: Library Unit of Graduate Program Sriwijaya University.

20. Ramayulis, 2011. Islamic Education. Jakarta: Kalam Mulia.

21. Rimland, Emily, 2013. "Assessing Affective Learning Using a Student Response System". Libraries and the Academy, 13(4): 385-401.

22. Sanjaya, Wina, 2006. Learning Strategy: the Standard Process of Education. Jakarta: Fajar Interpratama Offset.

23. Spradley, J.P., 1997. The Ethnographic Interviewer. Cambridge, MA: International Thomson

24. Sutrisno, Hadi, 2004. Research Methodology. Yogyakarta: Andi Publisher.

25. Team of Curriculum Development, 2010. Developing Education and Culture and National Character. Jakarta: Depdiknas.

26. The Rule of Ministry of Education and Culture No. 104 of 2014.

27. The Rule of Ministry of Education and Culture No. 66 of 2013.

28. The Rule of Ministry of National Education No. 20 of 2007.

29. Trianto, 2010. The Introduction for Research of Education. Jakarta: Kencana Prenada Media group.

30. Twersky, Fay. and Karen, Lindblom, 2012. Evaluation Principles and Practices Journal. http://www.hewlwtt.org/uploads/documents/EvaluationprinPrinciples-FINAL.pdf

31. Tyler, Ralp. W., 1949. Basic Principles of Curriculum and Instruction. Chicago: The University of Chicago Press.

32. Wahyuningsih, Rini, 2015. Assessment Analysis of Mathematics Teachers in Namungan Ma'arif Surabaya. Tesis UIN Sunan Ampel.

33. Wall, Janet E., 2004. "Program Evaluation Model 9-Step Process". Evaluation Journal. http://region11s4.lacoe.edu/attachments/article/34/\%287\%29\%209\%20Step\%20Evaluation\%20Model\%20 Paper.pdf

34. Whitelock, Denise and Cross, Simon, 2012. "Authentic Assessment: what Does It Mean and How is It Instantiated by a Group of Distance Learning Academics?" IJEA Journal, 2. http://journals.sfu.ca/index.php/journal/article/view/31 
